\title{
New Approach to Religion: \\ An Outlook to Edward E. Evan Pritchard's Theory OF RELIGION
}

\author{
Bakhruddin Fannani \\ Dosen Fakultas Tarbiyah Universitas Islam Negeri (UIN) Malang
}

\begin{abstract}
Sir Edward Evan Evans-Pritchard adalah antropolog Inggris terkenal, terutama dikenal karena penelitian yang dilakukannya terhadap budaya-budaya Afrika. Dia mendapat gelarkebangsawanan Inggris pada 1971. Minatnya ditujukan pada kajian antropologi sosial dan sistem kekerabatan pada berbagai suku-suku Afrika, terutama Zande dan Nuer di Sudan Selatan. Dua bukunya tentang dua suku ini, Witchraftt, Oracles, Old Magic Among the Azande (1973) and the Nuer (1940) membuat argumentasinya semakin terkenal dan memperoleh penghargaan akademis di bidangnya.
\end{abstract}

Keywords: approach, religion.

One of the great figures in modern anthropology was EdwardE. Evans Pritchard (1902-1973). He was a theorist of religion who actually entered two primitive societies, learned their language, lived for a time by their customs, and carefully studies in action. The study of anthropology in England had evolved from the older arm chair and library sort of research practiced by Muller, Tylor, and Frazer into a discipline that required at least apprenticeship of study devoted to a society very 123 different from those of modern Europe and America.

In London he was able to study with C. G. Seligman, who had been the first professional anthropologist to do field work in Africa. At the same time, Malinowski came to London and became a second mentor to him. He strongly encouraged Evans Pritchard to do what he had done in the Trobiand islands; studying the culture of a single people in great depth. Seligman encouraged him to choose a culture in Africa. 
Pritchard took the advice of both his mentors as he traveled to Sudan. He made several visits to a people known as the Azande in the southern Sudan. He spent two years with them and learned their language thoroughly. Between 1930-1936 he did further field work among the Nuer people of Sudan.

In 1937 he published his first major work, Witchcraft, Oracles, and Magic amont the Azande. It was followed by the of three volumes he was to published on the other tribe he had studied in depth, The Nuer: A Description of the Modes of Lifehood and Political Institution of a Nilotic People, in 1940. Hence he published numerous articles on anthropological subjects, the results of his work in Libya, The Sanusi of Cyrenaica (1944); Kinship and Marriage among the Nuer (1951); Nuer Religion (1956): Social Anthropology (1962); and A History of Anthropological Thought (1981, published after his death).

\section{A. Pritchard Approach to Anthropology}

Before Pritchard era there are at least two approaches to study anthropology (and especially religion). The first was older anthropology. It was inspired by a vision of a science of human affairs can be done by methodically collecting, comparing and classifying facts which come to an evolutionary conclusion as its end. Then, came later French Sociology which studies religion as a part of the formation of social grant. The new attitude of modern thinkers toward primitive people has change. The primitive people are equally but differently mature and intelligent human beings compared to modern people. What Pritchard did despite following French Sociology was going out into the field and makes a complete study of a single culture observing its religion, law, economics, class structure of kinship as an organic whole.

\section{B. Witchcraft, Oracles, and Magic among the Azande}

Again as his mentors had said, Pritchard asserted that magic is closely related to religion. Magic is the beliefs that certain aspects of life can be controlled by mystical forces or super natural forces. In case of the Azande 
which -according Pritchard — are logic, curios an inquiring, their significant part of life is dedicated to witchcraft, oracles, and other ritual performances.

Their idea of witchcraft comes from something unknown in everyone's body and can be inherited by taking it from the dead that seems only undigested food. It operates a mystical fashion to bring misfortune, sickness, and bad things on other people. The person who performs the witchcraft must be found to solve the case.

The other magic is poison oracles. It is performed by using a chicken for knowing the one who brings misfortune. It sometimes leads the death of the victim and vengeance must be done against the accused. The one who has the authority to bring the accused is the prince coming from the noble class. The nobles then are free from such accusation since the oracle only happens between the commoners. That is why the Prince becomes the anchor of entire legal system.

These practices are rational, coherent, and play a central role in social life of the Azande. They become a system of values regulating human conduct. Despite all this the Azande do not deny the explanation of the science since -as they say-there is no competition between science in one side and magic and religion in the other side. The previous can not kick out the latter. Both simply work alongside and with it.

In the Azande's case, the intellectual ingenuity and keens is conditioned by patterns of ritual and mystical beliefs. If the ritual and practices of magic do not give the answer, they simply consider that because they are not performed properly. So, the beliefs are fundamental, beyond dispute, impossible to shake and taking at all costs be preserved.

\section{Nuer Religion}

The Nuer concept of religion is based on Kwoth which means spirit. The first and the most high one is called Kwoth nhial meaning spirit of the sky or god. Nuer people consider themselves nothing before god. He is omnipotent and every thing. If a bad thing happens, the Nuer people refer to themselves as they believe that it is their fault which causes it. 
The Nuer concept of god falls into two main groups. The spirit of above and the spirit of below related to Kwoth nhial. They are Deng (the son of god), Mani (the spirit who leads the war), Niu (the god of the clan assembled), and Buk (a female spirit) called the mother of Deng. Though their places are in the sky, they can seize and enter into the human bodies by sickness. The people recognized as prophets are the people who are permanently possessed by the spirit, or one might say the owners of spirit.

It is hard to understand the role of secondary kwoth. The Nuer think their spirit has their own identity, separate and distinguishable from each other. Thus, Kwoth position is between god and humanity, they are lesser spirits. They take the totem animal to be physical symbol of the totem spirit which is a manifestation of Kwoth. The totem animal is always less important than the totem spirit.

Nuers believe that their family has a guardian. The Colwic is the family guardian who provides relation between their gods and their social structure. The Nuers recognize totem spirit which they associate with animal species consistent with totemic customs elsewhere, members of a specific tribe or clan are said to give respect to their totem animal.

Evan Pritchard's standpoint is that the Nuers think of spirit or God retracted into different bands or levels of divine power that apply in a particular way in different clans or social groups. The Nuers believe that God, the spirit of the sky is worshipped through simple prayer and sacrifice, while hymns, possession and divination become more common as people descend through the spirits of the air and down to the spirits of the below on the hierarchy of spirits and its other eldest of the spirits. Spirits of the air are his children; totemic spirits are the children of god's daughters.

The Nuer religion has many symbols using animals, such as bird. The birds closely related to the spirit of air. As the Nuers said later on these birds are daughters of God. In this view many scientists such as Levy-Bruhl consider the Nuer are mentally prelogical. In Pritchard's opinion; the primitive people like the Nuer use imaginative way of describing the world, analogies, figures, symbols and metaphors as rules of language.

In the Nuer opinion, there are three parts of human being: the flesh, the life (the breath) and the soul (or intellect). When the human dies the 
flesh goes under ground and decays. Meanwhile the life goes back to God, and the soul goes around for a time near the realm of the living until it eventually disappears.

Evans Pritchard said that if a person was a sinner when he was alive and then died before a reconciliation his ghost can be in trouble. Hence, it is necessary to make a sacrifice to the ghost. Pritchard concluded that the deads and their ghost are rather quickly forgotten in Nuer life. The soul is a part of all human beings and it is created.

The other important things in Nuer religion are sin and sacrifice. The idea of the sin is central to understanding the human side of Nuer religion. Among the Nuer as in other tribal cultures, various things are prohibited out of respect for the others. The Nuer said the concept is Thek (respect). If someone walks against the prohibited his consequence will be sickness. In this case to save his life, people ought to make an appropriate sacrifice to God. The function of sacrifice can be to recon ciliate with God and to maintain a good relation to society.

What Pritchard did was made corrections to what his predecessors did before in account with primitive religion and showing how complex and comprehensive religious system that a primitive society had had.

\section{Theories of Primitive Religion}

As an anthropologist, Evan Pritchard expanded the discussion of primitive religion in his book, Theories of Primitive Religion, in a different way bay contrasting his ideas to those of his predecessors from the psychological and sociological approaches. He said that the actual facts of the earlier approaches were misunderstood. Because only few of those scholars were involved directly in the primitive culture, they were unable to understand to some extend, how primitive people think, believe in something, interact with each other and so forth. They just make assumptions on that matter.

Moreover theorists from psychological background think that primitive people can think like they do and can explain everything concerning the world order. On the other hand, Pritchard has noticed that sociologists 
have done a somewhat better job, but not by much. They see primitive religion as part of their culture, which create their own language, values, and ideas. So, their thought is not to work and understand it from inside. He also suggested that the survival of any given society is dependent and something like science and of course, religion.

\section{E. Conclusion}

Evans Pritchard asserted that to draw better explanation on religion, scholars should work rather harder and to the research outside libraries and theological text and report. A religion should be explained in a way that it is developed by its believers, not from priests and theologians teachings.

\section{Bibliography}

Hopfe, Lewis M.; Woodward, Religions of the World, Prentice Hall, New Jersey, 1998

Pals, Daniel L., Seven Theories of Religion, Oxford University Press, New York, 1996.

Sheed Rosemary, Pattern in Comparative Religion, Meridian Books, New York, 1963. 